\title{
Epistimologi Teks dan Konteks dalam Memahami Al-Qur'an
}

\author{
Bahruddin
}

Dosen STAIN Majene

Email: bahruddin@stainmajene.ac.id

\begin{abstract}
Abstrak
Artikel ini membahas tentang diskursus antara teks dan konteks dalam memahami al-Qur'an. Disimpulkan bahwa upaya interpretasi dan pemaknaan al-Qur'an yang selalu berkutat dan bersembunyi di balik lafadh-lafadh teks akan menimbulkan kegamangan tersendiri. Hal ini akan tampak pada arus dinamika produksi makna al-Qur'an yang selalu kembali pada kedigdayaan teks. Sementara itu, upaya tekstualisasi atau penundukan al-Qur'an atas konteks tidak berarti dimaksudkan untuk mengeliminasi kesakralannya sebagai sabda Allah, tetapi justru dengan begitu, relevansi fungsi-fungsi al-Qur'an akan selalu hidup di tengah dinamika sosial historis manusia.
\end{abstract}

Kata Kunci: Teks, Konteks, al-Qur'an

\section{Pendahuluan}

Al-Qur'an sebagai Kitab petunjuk (hudan) memiliki posisi sentral dalam kehidupan umat Islam. Ia bukan saja sebagai landasan bagi pengembangan dan perkembangan ilmu-ilmu keislaman, namun ia juga merupakan inspirator, pemandu dan pemadu gerakan-gerakan sepanjang empat belas abad lebih sejarah umat Islam. Hal ini bisa terlihat dari dari munculnnya berbagai gerakan semisal Ikhwanul Muslimin di Mesir, Jam'at Islami di Pakistan, Wahabi di Saudi Arabia, NU dan Muhammadiyah di Indonesia, dan organisasi Islam lainnya di seluruh dunia. 
Salah satu keyakinan umat Islam terkait dengan al-Qur'an adalah bahwa ia diturunkan Allah kepada Nabi Muhammad melalui wadah wahyu. Dengan kata lain, al-Qur'an adalah verbum dei atau Kalam Allah yang diwahyukan kepada Nabi Muhammad melalui perantaraan Jibril. ${ }^{1}$ Catatan sejarah menunjukkan bahwa al-Qur'an turun tidak sekaligus, melainkan secara qradual selama kurang lebih 23 tahun yang secara periodik terbagi at as periode Makkah dan periode Madinah. Hal ini menunjukkan bahwa alQur'an hendak menegaskan dirinya bahwa ia ada untuk kepentingan manusia dengan segala dinamika sosiokulturalnya. Pada sisi lain, bagi umumnya pengamat Barat al-Qur'an dipandang sebagai Kitab yang sulit dipahami dan diapresiasi. Bahasa, gaya, dan aransemen Kitab ini dalam pandangan mereka pada umumnya telah menimbulkan masalah tersendiri. Masa pewahyuannya yang terbentang kurang lebih 23 tahun merefleksikan perubahan-perubahan lingkungan, perbedaan dalam gaya dan kandungan, bahkan ajarannya. ${ }^{2}$

Sekalipun bahasa Arab yang digunakannya dapat dipahami, terdapat bagaian-bagian tertentu di dalamnya yang masih dipandang sulit dipahami. Di kalangan kaum muslim sendiri telah dihasilkan berjuta-juta lembar tulisan tafsir sebagai upaya keras memahami maknanya, tetapi masih tetap menyisahkan ruang-ruang kabur, bahkan mungkin gelap sama sekali. Ruang-ruang tersebut kemudian diistilahkan oleh para komentator al-Qur'an (mufassir) sebagai ayat-ayat mutasyabihat. Terhadap ayat-ayat sejenis ini, para mufassir umumnya hanya berkomentar dengan satu kalimat pendek "wallahu a'lam bimuradihi" (hanya Allah yang tahu persis maksudnya).

Al-Qur'an dipandang sebagai himpunan wahyu Allah yang paling terakhir diturunkan kepada manusia dari rangkaian panjang wahyu-wahyu Allah terdahulu. Hal ini semakin dikuatkan dengan ditetapkannya Muhammad sebagai Nabi dan Rasul terakhir (khatam al-nabiyyin). Dari kenyataan inilah awal mula munculnya perdebatan panjang di sekitar teks dan konteks al-Qur'an. Pertanyaan paling krusial tentang hal ini adalah bagaimana harus dijelaskan bahwa al-Qur'an yang mewujud dalam bentuk teks berbahasa Arab dan turun kurang lebih empat belas abad lalu itu masih tetap valid hingga saat ini sehingga dapat dijadikan pedoman atau petunjuk bagi manusia?

Di seputar berdebatan inilah yang akan dicoba dibahas dalam tulisan ini. Pembahasan ini tidak dimaksudkan untuk mengurangi wibawah al1.

${ }^{1}$ Taufiq Adnan Amal, Rekonstruksi Sejarah al-Qur'an (Jakarta: Alvabeta, 2005), h.

${ }^{2}$ Ibid., h. 2 . 
Qur'an sebagai Kitab Suci yang bersumber dari yang Maha Suci, Allah Azza Wajallah, tetapi lebih dimaksudkan untuk mendayaguna-kan fungsinya sebagai pedoman dan petunjuk (hudan) bagi manusia. Hal ini penting, sebab jika al-Qur'an hanya diposisikan sebagai bacaan semata tanpa selalu diupayakan untuk menggali makna, maksud dan tujuannya, ia akan menjadi barang antik yang disakralkan tanpa makna.

Masalah yang akan dikaji dalam makalah ini adalah perdebatan tentang al-Qur'an sebagai teks dan perdebatan tentang al-Qur'an sebagai teks dengan konteks.

\section{Pembahasan}

\section{Perdebatan Tentang Teks al-Qur'an}

Benar, bahwa banyak aspek yang menjadi perdebatan tentang alQur'an, baik di kalangan ulama terlebih lagi di kalangan orientalis, namun satu hal yang agaknya disepakati bahwa al-Qur'an adalah teks keagamaan yang tertulis dalam bahasa Arab. Selain karena faktanya demikian, juga telah ditegaskan dalam al-Qur'an sendiri. ${ }^{3}$ Pertanyaannya kemudian adalah, apakah keber-bahasa-Arab-an al-Qur'an tersebut adalah bagian integral dari wahyu? Pertanyaan ini akan menyeret pertanyaan selanjutnya yang lebih dalam, yakni apakah al-Qur'an (teks) tersebut bersifat azali yang karenanya ia qadim ataukah ia dicipta yang karenanya ia hudus atau baru. Persoalan ini telah menimbulkan perdebatan tajam di kalangan teolog atau mutakallimin klasik.

Para teolog Mu'tazila misalnya berpandangan bahwa al-Qur'an itu baru dan makhluk karena ia tidak termasuk dalam sifat-sifat Dzat Allah yang azali. Al-Qur'an adalah firman Allah dan firman termasuk tindakan, bukan sifat. Dari segi ini makna al-Qur' an masuk dalam kategori "sifatsifat tindakan Allah" dan bukan kategori "sifat-sifat Dzat Allah". Kedua kategori ini dibedakan Mu'tazila sebagai berikut: Kategori pertama (sifatsifat tindakan) merupakan wilayah interaksi antara Tuhan dengan dunia, sementara kategori kedua "sifat-sifat Dzat Allah" merupakan wilayah keunikan dan kekhususan eksistensi Allah dalam Dzat-Nya sendiri. ${ }^{4}$ Artinya, yang terakhir ini tidak terkait dengan dunia, yakni sebelum terwujudnya dunia dan sebelum penciptaannya dari ketiadaan. Ini bisa

${ }^{3}$ Penegasan bahwa al-Qur'an diturunkan dalam bahasa Arab dite-gaskan dalam dua surah, yakni dalam Q.S. Yusuf (12):2 dan Q.S. Ibrahim (14):4:

${ }^{4}$ Nasr Hamid Abu Zaid, Teks Otoritas Kebenaran, diterjemahkan dari edisi Arabnya “An-Nashr, as Sulthan, al-Haqiqah” oleh Tim LKiS, (Yogjakarta: LKiS, 2003), h. 87. 
dijelaskan misalnya sifat keadilan Tuhan yang tidak mungkin dipahami kecuali dalam konteks adanya wilayah bagi realisasi sifat tersebut. Sama halnya dengan sifat Pemberi Rezki (al-Raziq) yang selalu terkait dengan adanya pihak yang diberi rezki, yakni alam semesta ini, dan begitu seterusnya.

Sifat firman Tuhan termasuk dalam kategori "sifat-sifat tindakan". Dengan begitu ia meniscayakan audensi yang menjadi sasaran komunikasi pihak pembicara. Jika dibayangkan Tuhan berfirman sejak zaman azali dalam pengertian firman-Nya (al-Qur'an) adalah qadim maka ini berarti Allah adalah pembicara tanpa audens karena alam masih belum ada, dan itu bertentangan dengan hikmah ketuhanan. Berbeda dengan ini, sifat-sifat Dzat adalah sifat-sifat yang keberadaannya tidak terkait dengan keberadaan dunia seperti ilmu, kuasa, hidup dan lain-lain. ${ }^{5}$

Berlawanan dengan Mu'tazila, para mutakallim (teolog) lain berpendapat bahwa firman Allah merupakan salah satu dari sifat-sifat Dzat-Nya. Dari sini mereka menyatakan bahwa al-Qur'an adalah firman yang azali dan qadim karena ia termasuk sifat Dzat Allah tersebut. Sebagai bukti mengenai semua ini adalah bahwa penentuan mengenai hakikat al-Qur'an adalah persoalan khilafiah di kalangan kaum muslimin sendiri. Menanggapi kedua kutub pendapat di atas, muncul golongan Asy'ariah yang berupaya mengambil jalan tengah, walaupun kelihatannya kurang berhasil. Mereka menyatakan bahawa al-Qur'an memiliki dua aspek; pertama aspek yang azali dan qadim, yakni firman Allah dalam Dzat-Nya sendiri yang mereka istilahkan sebagai "al-qalam al-nafs al-qadim" (firman kedirian yang qadim), dam kedua; adalah al-Qur' an yang dibaca saat ini yang merupakan salinan dari firman yang disebutkan sebelumnya. ${ }^{6}$

Perdebatan di atas tampaknya lebih terfokus pada hakikat eksistensi teks al-Qur'an kaitannya dengan wahyu (firman) Allah dan bersifat teologis. Namun demikian, perdebatan tersebut justru berinplikasi kuat terhadap proses pemaknaan teks (al-Qur'an) dalam relasinya dengan konteks. Pandangan kelompok Mu'tazila melahirkan pemikiran tentang dimungkinkannya memandang al-Qur'an sebagai teks yang tidak sunyi dari pengaruh sosio-historis, kalau tidak dapat dikatakan sebagai produk budaya. Dari sisi inilah lahir istilah historitas teks al-Qur'an. Sedangkan pandangan kedua melahirkan sikap memandang teks al-Qura' an sebagai sesuatu yang suci dan "sakral", dalam arti mustahil telah dan akan dipengaruhi oleh anasir-

${ }^{5}$ Ibid.

${ }^{6}$ Ibid. h. 88. Bandingkan dengan Muhammad Abu Zahra, Aliran Politik dan Aqidah dalam Islam, diterjemahkan dari edisi Arab "Tarikh al-Mazahib al-Islamiyah" oleh Abd. Rahman Dahlan dan Ahmad Qarib, (Jakarta: Logos, 1996), h. 175-187. 
anasir sosio-historis. Dari rahim pandangan inilah kemudian mun-cul pandangan yang memandang teks (al-Qur'an) memiliki otoritas ke-benaran mutlak, bahkan sama seperti mutlaknya kebenaran Tuhan itu sen-diri.

Pandangan Mu'tazila yang telah dikemukakan sebelumnya agaknya menjadi semacam legitimasi bagi beberapa pemikir Islam kontemporer. Salah satu di antaranya adalah Nashr Hamid Abu Zaid. Ia berpandangan bahwa al-Qur'an sebagai sebuah teks pada dasarnya adalah produk budaya. Hal ini dapat dibuktikan dengan rentan waktu terkumpulnya teks al-Qur'an selama kurang lebih 23 tahun yang terbentuk dalam resalitas sosial dan budaya. ${ }^{7}$ Oleh karena itu, diperlukan adanya dialektika yang terus menerus antara teks al-Qur'an dan kebudayaan manusia yang senan-tiasa berkembang secara pesat. Jika hal ini tidak dilakukan, maka teks al-Qur'an akan hanya menjadi benda atau teks mati yang tidak berarti apa-apa dalam kancah fenomena kemanusiaan. Teks al-Qur'an masih sangat mungkin menjadi obat mujarrab, bacaan shalat, atau perhiasan bacaan yang dikumandangkan tiap waktu. Akan tetapi visi transformatif dan kemanusiaan al-Qur'an akan hilang begitu saja.

Abu Zaid berpendapat bahwa ada tiga alasan untuk menunjukkan tekstualitas al-Qura'an, yakni (1) al-Qur'an adalah pesan Allah yang diwahyukan kepada Nabi Muhammad melalui kode komunikasi bahasa Arab via Jibril. Sebagai pesan, al-Qur' an meniscayakan dirinya untuk dikaji sebagai sebuah teks, (2) urutan-urutan al-Qur'an yang ada di tangan kita sekarang tidak sama dengan kronologi pewahyuan (tartib nuzul). Urutan kronologis pewahyuan menunjukkan sifat realitas teks, sementara struktur kronologi pembacaan (tartib tilawah) yang ada sekarang menunjukkan teks-tualitasnya, dan (3) adanya kenyataan bahwa al-Qur'an terdiri ayatayat muhkamat yang menjadi "inti" teks, dan ayat-ayat mutasyabihat yang harus dipahami berdasar pada ayat-ayat muhkamat itu. ${ }^{8}$

Perdebatan panjang tentang teks al-Qur'an tampaknya akan terus berlanjut, sebab berawal dari persoalan menyangkut teologi atau terkait dengan ke-Esahan Allah. Tentu saja masing-masing pihak akan mempertahankan pendapatnya dengan berbagai argumen yang sedapat mungkin ditunjukkan pada masing-masing pihak.

${ }^{7}$ Nasr Hamid Abu Zayd, Teks Otoritas Kebenaran. Diterjemahkan dari edisi Arabnya "An-Nashr, as Sulthan, al-Haqiqah" oleh Tim LKiS (Yogjakarta: LKiS, 2003), h. 27.

\footnotetext{
${ }^{8}$ Ahmad Fawaid Sjadzili, Memanusiakan al-Qur'an. Dikutip dari
} 
Dalam menyikapi kedua pendapat di atas, penulis lebih condong pada pendapat kedua, yakni bahwa al-Qur'an pada dasarnya adalah makhluk. Konsekuensi dari keberpihakan ini adalah bahwa teks al-Qur'an selayaknya dipandang sebagai sebuah produk budaya. Hal ini tidaklah berarti mengingkari ke-wahyu-an al-Qur'an. Ia tetaplah sebagai wahyu, akan tetapi ketika ia sudah mendarat di bumi dalam arti diucapkan (di-baca) dan ditulis, maka pada saat itu ia telah telah menjadi produk budaya.

Ada kegagapan tersendiri jika al-Qur'an tetap dipandang sebagai bukan ciptaan, yakni bahwa al-Qur'an akan menjadi azali dan qadim. Konsekuensi dari pemahaman ini adalah bahwa ada kehawatiran yang mendasar akan terjerumus kepada pensakralan al-Qur'an seperti pensak-ralan terhadap Allah. Jika ini terjadi, maka apa bedanya kaum Nashrani ketika mereka mengatakan bahwa Isa adalah Firman Allah yang azali, dan karenanya Ia memiliki sifat-sifat ke-Tuhanan? Tentu saja penulis tidak bermaksud men-desakralisasi al-Qur'an. Ia tetap sakral karena bersumber dari Allah, namun meminjam istilah Abu Zaid al-Qur'an harus dimanusiakan (tamauwdha'a fiha basyarian), atau dirunkan ke ranah sosiologis sebab kesakralan al-Qur'an baru bermakna ketika ia diposisikan secara demikian. Tampa bermaksud mengurangi kesuciannya, upaya memanusiakan alQur'an pada dasarnya adalah upaya memposisikannya pada tempat yang dapat dicandra oleh pemahaman manusia agar ia benar-benar dapat berdialog dalam laskap sosio-historis manusia secara terbuka. Dengan begitu, fungsi hudan yang diembannya benar-benar dapat terrealisasi.

\section{Perdebatan Tentang Teks dalam Kaitannya dengan Konteks}

Dengan menyatakan bahwa teks al-Qur'an adalah produk sejarah, maka ia dapat disamakan dengan teks-teks lainnya, dalam arti dapat didekati dengan pendekatan linguistik dan bahkan kritik sastra. Artinya, layaknya teks-teks lain, al-Qur'an sangat mungkin didekati dengan berbagai perangkat kajian tekstual modern.

Dalam kaitan ini pendekatan hermeunetika sangat mungkin digunakan dalam membaca al-Qur'an dalam kaitannya dengan konteks. ${ }^{9}$ Ada

${ }^{9}$ Secara sederhana Hermeunetika dapat diartikan sebagai sebuah sistim interpretasi makna yang digunakan manusia untuk meraih makna di balik simbol (termasuk symbol tertulis/teks). Untuk memahami lebih mendalam tentang hermeunetika dapat ditelusuri dalam Richard E. Palmer, Hermeunetika: Teori Baru Mengenai Interpretasi, diterjemahkan dari edisi Inggris "Hermeunetics: Interpretation Theory in Schleinmacher, Heiddegar, and Gadamer" oleh Mansur Hery dan Damanhuri Muhammad, (Yogjakarta: Pustaka Pelajar, 2003), h. 38-39. 
tiga pertanyaan mendasar jika hermeunetika ingin digunakan dalam membaca al-Qura'an sebagai teks, yakni (1) apa isi teks? Dalam hal ini peran mufassir adalah menerjemahkan teks al-Qur'an ke dalam bahasa lain (misalnya bahasa Indonesia) yang baik dan benar. Bukan hanya terjemah kata perkata, tetapi transfer makna teks ke dalam bahasa Indonesia, (2) situasi dan kondisi apa yang mendorong lahirnya teks ini? Pertanyaan ini terkait dengan sistuasi sosio-historis (konteks) teks al-Qur'an. Peran mufassir di sini adalah memberi konteks sejarah dan kultural pada al-Qur'an. Bukan semata-mata kajian asbab al-nuzul, namun lebuh dari itu menempatkan alQur'an sebagai produk masyarakat dan budaya tertentu, dan (3) apa arti teks untuk saya? Dalam hal ini mufassir berfungsi sebagai "kontekstor" yakni upaya menggabungkan teks dan koteks dalam wilayah kekikinian. Untuk itu, seorang "kontekstor" mesti memahami situasi-kondisi "dunia" yang ditempatinya. ${ }^{10}$

Hermeneutika sebagai sebuah metode interpretasi sangat relevan dipapakai dalam memahami pesan al-Qur'an agar subtilitas inttelegendi (ke-tepatan pemahaman) dan subtilitas ecsplicandi (ketepatan penjabaran) dari pesan Allah bisa ditelusuri secara komprehensif. Maksudnya, pesan Allah yang diturunkan pada teks al-Qur'an melalui Nabi Muhammad itu tidak hanya dipahami secara tekstual, juga bisa kita pahami secara kontekstual dan menyeluruh dengan tidak membatasi diri pada teks dan konteks ketika al-Qur'an turun, maka, teks al-Qur'an beserta yang melingkupinya dapat digunakan agar selaras dan cocok dengan kondisi ruang, waktu, dan tempat di mana kita berada dan hidup. Diskursus hermeneutika tidak bisa dilepaskan dari bahasa, karena problem hermeneutika adalah problem bahasa. Karena itu, dalam memahami teks Al-Qur'an, disamping harus memahami kaidah tata bahasa, juga mengandaikan suasana psikologis dan sosio historis (wacana) yang teks tersebut. Atau dengan kata lain, istilah teknis yang diciptakan Ferdinand de Saussure di atas -seorang ahli bahasa dari Swis adalah hubungan yang dialektis antara teks dan wacana. ${ }^{11}$

Sebuah penafsiran dan usaha pemahaman terhadap al-Qur'an jika memakai metode hermeneutika, selalu terdapat tiga faktor yang senantiasa dipertimbangkan, yaitu dunia teks, dunia pengarang, dan dunia pembaca. Ketiga komponen itu memiliki konteks sendiri-sendiri, sehingga jika

10 Yasser Muhammad, Tiga Pertanyaan Hermeunetika Al-Qur'an, dikutip dari

11 K. Bertens, Filsafat Barat Abad XX (Jakarta: Arruz Media, 1995), h. 34. Bandingkan dengan Yasraf Amir Piliang "Kata Pengantar" dalam Alex Sobur, Semiotika Komunikasi, (Bandung: Remaja Rosdakarya, 2006), h x-xi. 
memahami teks al-Qur'an hanya bertumpu pada satu dimensi tanpa mempertimbangkan dimensi yang lainnya, pemahaman yang diperoleh tidak akan luas dan miskin. Dalam tradisi hermeneutika, terutama metode yang diperkenalkan oleh Gadamer, akan terlihat jelas bahwa dalam setiap pemahaman teks, tidak terkecuali pada teks al-Qur' an, unsur subjektivitas penafsir tidak mungkin disingkirkan. Bahkan secara ekstrem dikatakan bahwa sebuah teks akan berbunyi dan hidup ketika dipahami, diperhatikan, dan diajak dialog oleh pembacanya. ${ }^{12}$ Dalam proses dialog tersebut, berarti pihak pembaca memiliki ruang kebebasan dan otonomi. Munculnya kitab tafsir al-Qur'an yang berjilid-jilid yang masih dan akan terus berkembang menunjukkan bahwa pemahaman ulama' pada al-Qur'an dan tradisi kenabian tidak pernah final.

Dalam konteks itulah terdapat beberapa upaya untuk mendialogokan teks al-Qur'an dengan konteks sosial historis manusia, baik dalam kaitannya dengan upaya perumusan kaidah-kaidah tafsir maupun dan upaya istimbatnya. Untuk yang pertama penulis menampilkan upaya se-orang tokoh muda NU, Muqshith Gozali, yang mencoba merumuskan kaidahkaidah tafsir yang baru -yang- tampaknya keluar dari tradisi ulama yang selama ini telah mapan. Kemudian, dalam konteks istimbat hukum akan ditampilkan pemikiran dua tokoh ulama Indonesia dipandang mum-puni dalam bidangnya, yakni KH. Ibrahim Hossen tentang hukum potong tangan dan KH. Munawir Sadzali tentang pembagian harta waris antara anak lakilaki dan perempuan.

\section{Pandangan Muqshith Gozali}

Muqshith Gozali berpandangan bahwa sudah saatnya para ulama merumuskan kembali hirarki sumber hukum Islam. Jika para selama ini para ulama menempatkan al-Qur'an diurutan pertama pada hirarki sum-ber hukum Islam, maka saatnya untuk mempertimbangkan maqashid sya-ri'ah untuk menggantikan al-Qur'an. Alasannya, adalah bahwa apa yang dipahami oleh ulama selama ini sebagai al-Qur'an pada dasarnya adalah teks al-Qur'an itu sendiri. Padahal, tegas Muqshit, yang semestinya menjadi pertimbangan utama dalam menarik makna dan maksud al-Qur'an bukanlah makna literal teks, tetapi apa yang dibalik teks tersebut. Bagi Muqshith makna di balik teks tersebut adalah maqashid al-syari'at. ${ }^{13}$ Oleh

12 Ahmad Fuad Fanani, Metode Hermeunetika untuk Al-Qur'an, dikutip dari

${ }^{13}$ Abd Muqshith Gozali, Metode dan Kaidah Penafsiran Al-Qur'an. Makalah tidak dipublikasikan, disampaikan pada Konfrensi Regional Perkembangan Pemikiran Islam 
karena itu, menempatkan maqasid al-syari'at sebagai urutan pertama dalam hirarki sumber hukum Islam adalah sebuah keniscayaan.

Dalam kaitan inilah Muqshit Gozali mengajukan kritik terhadap paradigma fiqhi klasik yang selama ini banyak dianut kaum muslimin. Kritikan tersebut adalah (1) terlalu memandang sebelah mata terhadap kemampuan akal publik dalam menyulih dan menganulir ketentuanketentuan legal formal dalam Islam yang tidak lagi relevan. Dikatakan bahwa ketika terjadi pertentangan antara bunyi harfiah teks (al-Qur'an dan Hadis) dengan akal publik, ajaran metodolgi fikih klasik selalu mengambil cara menundukkan akal publik terhadap teks, (2) kurang hirau terhadap kemampuan manusia dalam merumuskan konsep kemaslahatan walau untuk manusia sendiri. Manusia tidak memiliki reputasi dan kedudukan apapun dalam ruang ushul fikih klasik, kecuali hanya sebagai sasaran hukum yang tak berdaya (mukallaf), dan (3) terlalu "memberhalakan" teks dan mengabaikan realitas. Aktifitas ijtihad memang ada, tapi selalu digerakkan di sekitar area teks. Ijtihad yang tidak demikian dianggap ilegal, sebab teks merupakan aksis dari seluruh cara memecahkan problem ${ }^{14}$

Karena maqashid al-syari'at berada pada posisi paling atas dalam hirarki sumber hukum Islam, maka sejatinya seluruh bangunan metodologi perumusan kaidah ushul fikih harus diacu padanya. Dalam konteks inilah Abd Muqshith Gozali mengajukan tiga rumusan kaidah umum ushul fiqh yang baru, yaitu (1) al-ibrah bi al-maqashid la bi al-alfadz, (2) naskh alnushus bi al-mashlat, dan (3) tanqih al-nushush bi al-aql mujtam". Ketiga rumusan kai-dah tersebut dapat dijelaskan sebagai berikut: ${ }^{15}$

\section{Al-ibrat bi al-maqashid la bi al-alfadz.}

Kaidah ini berarti "yang mesti menjadi pertimbangan seorang mujtahid dalam meng-istimbat-kan hukum dari Alquran dan Sunnah bukan huruf dan aksaranya, melaikan dari maqashid yang dikandungnya. Yang menjadi aksis adalah cita-cita etik-sosial dari sebuah ayat, bukan legislasi spesifik atau formulasi literalnya (teksnya). Untuk mengetahui maqashid ini seseorang dituntut untuk memahami konteks. Bukan hanya konteks personal yang juz'iy-partikular, melainkan juga dalam area konteks imper-

Kontemporer yang diselenggarakan oleh STAIN Ternate di Ternate, 22-24 Oktober 2004, h. 3-7

${ }^{14}$ Rumadi, Post Tradisonalisme Islam; Wacana Intelektualisme dalam Komunitas NU (Jakarta: Dirjen PTAI Kementrian Agama RI, 2007), h. 306.

${ }^{15}$ Ketiga kaidah dan seluruh penjelasannya dielaborasi dari Abd Muqshith Gozali, op. cit. 3-7. 
sonal yang kulliy-universal. Pemahaman tentang konteks yang lebih dari sekedar ilmu asbab al-nuzul dalam pengertian klasik itu, merupakan pra syarat utama untuk menemukan maqashid al-syari'at.

Kaidah di atas merupakan anti tesis dari kaidah lama yang berbunyi al-ibrat bi khushus al-sabab la bi umum al-lafdz (yang harus menjadi pertimbangan adalah keumuman lafadz bukan kekhususan sebab). Hal ini berarti bahwa jika suatu nash menggunakan redaksi yang bersifat umum, maka tidak ada pilihan lain kecuali menerapkan nash tersebut sekalipun nash itu hadir untuk merespon peristiwa khusus ribuan tahun lalu.

Pasrah pada keumuman lafadz hanya akan menyebabkan para mujtahid senantiasa berada dalam lingkaran makna linguistik. Analisis yang hanya berhenti pada konteks linguistik saja tidak akan cukup memadai untuk mengejar kebenaran hakiki yang diusung oleh teks. Analisis mestinya dilanjutkan pada penyingkapan makna yang terdiamkan, yaitu makna yang tak tercakup secara verbatin di dalam aksara sebuah teks. Pencapaian terhadap makna-makna itu akan meniscayakan adanya sebuah analisa yang bukan hanya terhadap struktur kalimat per se. Yang justru fundasional adalah analisa kelas dan struktur sosial dan budaya yang melingkupi sejarah kehadiran teks. Maka maqashid al-syari'ah dengan berbagai cara tanpa terlalu banyak terpesona terhadap keindahan sebuah teks. Sebab tindakan tersebut merupakan tata kerja idiologis yang hanya akan menumpulkan kreatifitas dalam pencarian makna objektif.

\section{Naskh al-nushush bi al-mashlahat}

Kaidah ini berarti mengabaikan nash demi kemaslahatan. Hal ini didasarkan pada asumsi bahwa tujuan diturunkannya syari'at Islam tidak lain kecuali untuk mewujudkan kemaslahatan manusia secara universal dan menolak segala bentuk kemudharatan. Ibnu Qayyim al-Jauziyah, se-orang ulama dari madzhab Hanafiy menyimpulkan bahwa syari'at Islam dibangun untuk kepentingan manusia dan tujuan-tujuan kemanusiaan universal yang lain, seperti; kemaslahatan, keadilan, kerahmatan, dan kebi-jaksanaan. Prinsip-prinsip ini haruslah menjadi dasar dan substansi dari seluruh formulasi hukum Islam. Ia harus senantiasa ada dalam pikiran para ahli fikih ketika mereka memutuskan suatu kasus hukum. Penyim-pangan terhadap prinsip ini berarti menyalahi cita-cita syari'at Islam.

Konsekuensi kaidah di atas kelihatannya agak ekstrem, kalau bukan sangat eksterim, sebab dengan mengacu pada kaidah tersebut berarti mashlahat memiliki otoritas untuk mengabaikan ketentuan-ketentuan makna literal teks suci. Sebagai spirit dari teks (nushush) Alquran atau Hadis, 
kemaslahatan merupakan amunisi untuk mengontrol balik dari keberada-an teks, dengan mengabaikan beberapa teks suci yang dianggap tidak rele-van dengan konteks. Dengan cara ini, maka cita rasa kemaslahatan akan senantiasa berkreasi untuk memproduksi formulasi bahan teks keagamaan baru di tengah kegamangan, kegagapan formulasi dan teks keagamaan lama.

Namun harus segerah dijalaskan bahwa nasakh tidak dapat diterapkan pada teks Alquran dan Hadis yang mengandung prinsip-prinsip yang universal. Ajaran mana telah melintasi ruang dan waktu, mengatasi pelbagai etnis dan keyakinan. Salah satu di antaranya, ayat tentang seruan untuk berlaku adil dalam memutuskan perkara. Mengabaikan ayat-ayat (teks/ nushush) yang demikian bukan saja bertentangan dengan semangat kehadiran Islam awal, melaikan juga bertentangan dengan logika nasakh sendiri. Sementara ayat-ayat mu'amalat yang bersifat teknis operasional, seperti ayat tentang bentuk-bentuk hukuman (uqubat), sanksi bagi para pelaku pidana (hudud), bilangan waris dan sebagainya, maka tetap terbuka kemungkinan untuk dinasakh (diabaikan) dan difalsifikasi, sekiranya ayatayat tersebut tidak efektif lagi sebagai sarana untuk mewujudkan cita kemaslahatan.

\section{Tanqih al-nushush bi al-aql al-mujtama'}

Arti kaidah ini adalah bahwa akal publik memiliki wewenang untuk menyulih dan mengamandemen ketentuan "dogmatis" agama yang menyangkut perkara publik, baik dalam al-Qur'an maupun dalam Sunnah. Artinya, ketika terjadi pertentangan antara akal publik dan makna lafadz teks, maka akal publik mempunyai otoritas untuk mengedit, menyempurnakan, dan mengkodifikasinya. Kodifikasi ini sangat dibutuhkan ketika berhadapan dengan ayat-ayat partikular, seperti uqubat dan hudud, misalnya; potong tangan, rajam, waris, dan sebagainya.

Dalam tradisi pemikiran Islam klasik dikenal aliran Mu'tazilah dan Asy'ariyah. Aliran ini berbeda dalam hal penggunaan akal dalam memaknai ayat Alquran dan teks Hadis. Mu'tazila memposisikan akal lebih banyak dan Asy'ariyah justru sebaliknya lebih sedikit. Namun demikian, baik Mu'tazilah maupun Asy'ariyah pada hakikatnya sama-sama memposisikan akal sebagai pengelola data-teks, sementara data-teks merupakan pangkal atau asal. Sebagai pengelola, akal tidak dapat bertindak terlampau jauh, kecuali hanya untuk melakukan rasionalisasi hal-hal irrasional yang ada dalam Alquran dan Sunnah. Akal hanya berguna untuk membuka tabir kegelapan teks-teks dhanni saja di tangan Mu'tazilah, akal hanya berfungsi 
untuk menakwilkan ayat-ayat mutasyabihat saja. Akal tidak dipercaya untuk melakukan peninjauan ulang, apalagi mempertanyakan, ayat-ayat partikular yang tergolong qath'iyat dari sudut struktur gramatika bahasanya.

Dari sisi inilah akal publik harus diberi posisi penting. Akal publik tidak cukup hanya tampil sebagai pengelola data teks, sepanjang menyangkut masalah-masalah mu'amalah yang partikular, ia perlu mendapatkan otoritas untuk mengevaluasi efektifitas dan kinerja beberapa ketentuan spesififik-legalistik al-Qur'an dan Sunnah di dalam mengimplementasikan maqashid al-syari'at di medan realitas (konteks). Jika dari fakta lapangan (konteks) diketahui ketidakberdayaan sebuah teks di dalam mengatasi perkara-perkara publik, maka akal publik mesti mempertibangkan ulang ketentuan tersebut.

\section{Pandangan KH. Munawir Sjadzali dan KH. Ibrahim Hossen}

\section{Munawir Sjadzali}

Munawir Sjadzali adalah seorang cendikiawan muslim Indonesia yang cukup dikenal. Selain karena ia pernah menjabat sebagai Menteri Agama, juga karena gagasan dan hasil pemikirannya yang sempat menjadi perbincangan, bahkan menimbulkan kontroversi, terutama oleh para kiyai. Gagasan tersebut dikenal dengan kontekstualisasi ajaran Islam, terutama al-Qur'an. Ia secara spesifik menyoroti salah satu ayat al-Qur'an yang bertalian dengan hak laki-laki dan perempuan dalam hal pembagian harta warisan. Sebagaimana diketahui bahwa al-Qur'an secara tegas menyebutkan bahwa antara laki-laki dan perempuan adalah 2 banding 1.2 untuk lakilaki dan 1 untuk perempuan (Q.S. Al-Nisa/4:11). Dalam salah satu tulisannya ia menyebutkan:

Ayat al-Qur' an tentang hukum waris untuk kondisi saat ini sudah tidak relevan lagi dengan perkembangan masyarakat. Karena itu, selama umat Islam berpendirian bahwa al-Qur'an itu final dan teks diartikan secara harfiah, maka Islam akan menjadi kendala bagi kemajuan dan pembangunan. Karena Alquran harus difahami kontekstual, maka ketentuan anak laki-laki berhak mendapatkan dua kali pembagian anak perempuan hanya relevan dengan masyarakat pada saat ayat itu diturunkan. Kalau ditelusuri alasan pember-lakuan pembagian warisan tersebut adalah karena kondisi masyarakat waktu al-Qur'an diturunkan, 
tanggung jawab memberi nafkah dipikul oleh pihak laki-laki terhadap saudara perempuannya maupun terhadap istrinya. Karena itu, wajar pada masa itu pembagian waris $2: 1$. Namun saat ini, ketentuan tersebut tidak cocok lagi diterapkan terhadap masyarakat di mana soal tanggung jawab memberi nafkah tidak lagi atau bukan hanya dipikul oleh pihak laki-laki. ${ }^{16}$

Dalam konteks maqashid al-syari'at, pembagian 2:1 ketika ayat tersebut turun tentulah sangat tepat dan adil serta sesuai dengan logika publik pada saat itu. Seperti diketahui bahwa sebelum al-Qur' an turun alihalih wanita mendapat warisan -berapapun bandingannya dengan laki-laki, dirinya-sendiri (wanita) dapat diwarisi oleh pihak laki-laki. Dalam kondisi seperti itu pembagian warisan 2:1 tentulah merupakan terobosan yang luar biasa bagi pemenuhan rasa keadilan masyarakat Arab dewasa itu. Sebaliknya, kondisi masyarakat Indonseia yang umumnya tanggung jawab mencari nafkah dipikul bersama oleh pihak laki-laki dan perempuan (suami-istri), naka pembagian waris 2:1 dapat dipandang sudah tidak proporsional dan tidak sesuai dengan semangat keadilan.

Dalam hal ini pandangan Munawir dapat dirujuk pada tiga kaidah sekaligus, yaitu, al- ibrah bi al-maqashid la bi al-alfadz, yakni yang menjadi pertimbangan dalam meng-istimbat-kan hukum adalah kemaslahatan, bukan makna literal lafadz (teks) ayat, naskh al-nushush bi al-mashlahat, yak-ni, mengabaikan nash demi kemashlahatan, dan tanqih al-nushush bi al-aql al-mujtama', yakni meninggalkan nash (teks) demi memenuhi akal publik. Dalam hal ini, Munawir memandang bahwa sangat tidak mashlahat pem-bagian warisan 2:1 -seperti yang disebut dalam makna literal ayatbagi kondisi masyarakat bangsa Indonesia saat ini. Karena itu, demi dan atas pertimbangan kemaslahatan, makna literal teks ayat tersebut harus diabai-kan.

\section{KH. Ibrahim Hosen}

Sebagaimana gagasan Munawir, gagasan Ibrahim juga sempat menjadi perbincangan hangat, ketika memberikan pandangan terhadap hukum potong tangan bagi pencuri, seperti disebutkan dalam Q.S. Al-Maidah/5:38, "Pencuri laki-laki maupun perempuan maka potonglah tangannya". Terhadap ayat ini, Ibrahim Hosen menjelaskan.

${ }^{16}$ Lihat A. Rahman Zainuddin, (et. All), Konteksrualisasi Ajaran Islam: 70 Tahun Prof. Dr. H. Munawwir Sjadzali (Cet. I; Jakarta: Paramadina, 1999), h. 89. 
Pembaharuan dalam hal hukum potong tangan bagi pencuri dapat ditempuh dengan mengacu pada asumsi bahwa dalam masalah pidana hendaknya ditekankan dari segi zawahir. Artinya, hukuman yang dilakukan dimaksudkan agar mereka (para pencuri) merasa jerah tidak akan mmengulangi tindak pidana lagi. Dengan demikian, hukuman tersebut tidak terkait dan terpaku pada apa yang tertera di dalam nash. Atas dasar ini, pencuri dapat saja di-hukum dengan hukuman selain potong tangan, asalkan saja mereka tidak mengulangi lagi perbuatan serupa dan membuat orang yang punya niat serupa mengurunkan niatnya, demikian juga hukuman bagi pezina. ${ }^{17}$

Pandangan Ibrahim di atas jelas merupakan sebuah terobosan baru, kalau bukan terobosan berani, sebab ia secara tegas mengabaikan makna literal ayat. Menurut Ibrahim potong tangan bagi pencuri dapat saja diganti dengan bentuk hukumaman lain, jika saja bentuk hukuman tersebut dapat memenuhi mashlahat atau maqashid al-syari'at, yakni pelaku pencurian menjadi jera dan tidak akan berniat mengulangi pebuatan tersebut. Hal ini sesuai dengan kaidah, naskh al-nushsuh bi al-mashlahat, yakni nash dapat diabaikan demi kemashalatan.

\section{Penutup}

Berdasarkan penjelasan sebelumnya dapat dikemukakan bahwa perdebatan panjang tentang al-Qur'an antara tekas dan konteks akan terus berlanjut, sebab persoalan ini pada awalnya bersumber dari perdebatan teologis yang menyangkut kesakralan al-Qur'an sebagai wahyu, bahkan menyangkut eksistensi ke-Esaan Allah.

Upaya interpretasi dan pemaknaan al-Qur' an yang selalu berkutat dan bersembunyi di balik lafadh-lafadh teks akan menimbulkan kegamang-an tersendiri. Hal ini akan tampak pada arus dinamika produksi makna alQur'an yang selalu kembali pada kedigdayaan teks.

Sementara itu, upaya tekstualisasi atau penundukan al-Qur'an atas konteks tidak berarti dimaksudkan untuk mengeliminasi kesakralannya sebagai sabda Allah, tetapi justru dengan begitu, relevansi fungsi-fungsi alQur'an akan selalu hidup di tengah dinamika sosial historis manusia.

${ }^{17}$ Ibid., h. 253-270. 


\section{Daftar Pustaka}

Adnan Amal, Taufiq. Rekonstruksi Sejarah al-Qur'an. Jakarta: Alvabeta, 2005.

Abu Zaid, Nasr Hamid. Teks Otoritas Kebenaran. Diterjemahkan dari edisi Arabnya "An-Nashr, as Sulthan, al-Haqiqah" oleh Tim LKiS, Yogjakarta: LKiS, 2003.

----------. Hermeunetika Ingklusif: Mengatasi Problematika Bacaan dan Cara-Cara Pentakwilan atas Diskursus Keagamaan. Diterjemahkan dari edisi Arab-nya "Isykaliayat al-Qira'at wa Aliyyat al-Ta'wil" oleh Muhammad Mansur dan Khoirian Nahdiyyin, Jakarta: ICIP, 2004.

Sjadzili, Ahmad Fawaid. Memanusiakan al-Qur'an. Dikutip dari

Gozali, Abd. Muqshith. Metode dan Kaidah Penafsiran Al-Qur'an. Makalah tidak dipublikasikan, disampaikan pada Konfrensi Regional Perkem-bangan Pemikiran Islam Kontemporer yang diselenggarakan oleh STAIN Ternate di Ternate, 22-24 Oktober 2004.

Zainuddin, A. Rahman. (et. All), Konteksrualisasi Ajaran Islam: 70 Tahun Prof. Dr. H. Munawwir Sjadzali,Cet. I; Jakarta: Paramadina, 1999.

Palmer, Richard E. Hermeunetika: Teori Baru Mengenai Interpretasi. Diter-jemahkan dari edisi Inggris "Hermeunetics: Interpretation Theory in Schleinmacher, Heiddegar, and Gadamer" oleh Mansur Hery dan Damanhuri Muhammad, Yogjakarta: Pustaka Pelajar, 2003.

Bertens, K. Filsafat Barat Abad XX, Jakarta: Arruz Media, 1995.

Piliang, Yasraf Amir. "Kata Pengantar" dalam Alex Sobur, Semiotika Komunikasi. Bandung: Remaja Rosdakarya, 2006.

Abu Zahra, Muhammad. Aliran Politik dan Aqidah dalam Islam. Diterjemahkan dari edisi Arab "Tarikh al-Mazahib al-Islamiyah" oleh Abd. Rahman Dahlan dan Ahmad Qarib. Jakarta: Logos, 1996.

Rumadi, Post Tradisonalisme Islam; Wacana Intelektualisme dalam Komunitas NU. Jakarta: Dirjen PTAI Kementrian Agama RI, 2007.

Fanani, Ahmad Fuad. Metode Hermeunetika untuk Al-Qur'an, dikutip dari 